Article

\title{
Innovative Forms of Citizen Participation at the Fringe of the Formal Planning System
}

\author{
Torill Nyseth ${ }^{1, *}$, Toril Ringholm ${ }^{1}$ and Annika Agger ${ }^{2}$ \\ ${ }^{1}$ Department of Social Sciences, Uit, The Arctic University of Norway, 9019 Troms $\varnothing$, Norway; E-Mails: torill.nyseth@uit.no \\ (T.N.), toril.m.ringholm@uit.no (T.R.) \\ 2 Department of Social Sciences and Business, Roskilde University, 4000 Roskilde, Denmark; E-Mail: aagger@ruc.dk \\ * Corresponding author
}

Submitted: 6 July 2018 | Accepted: 5 September 2018 | Published: 24 January 2019

\begin{abstract}
In the Nordic countries, we are witnessing a proliferation of novel and more experimental ways of citizen and authority interaction within the field of urban planning and governance. These formats are seen in urban regeneration projects and planning experiments that endorse more inclusive interactions between public authorities and local actors than in the traditional formal hearings. The intention of this article is to explore the potential of these forms of participation in contributing to social innovation particularly related to including citizens that are difficult to reach, and in creating new arenas for interaction and collaboration. Theoretically, the article is inspired by the concepts of social innovation, planning as experimentation (Hillier, 2007; Nyseth, Pløger, \& Holm, 2010), and co-creation (Voorberg, Bekkers, \& Tummers, 2013). Empirically, the article draws on three different cases from Norway and Denmark which entailed some novel ways of involving local citizens in urban planning. Finally, the article discusses how formal planning procedures can gain inspiration from such initiatives.
\end{abstract}

\section{Keywords}

citizen participation; co-production; experimental planning; social innovation

Issue

This article is part of the issue "The Transformative Power of Urban Planning through Social Innovation", edited by Torill Nyseth (UiT, The Arctic University of Norway, Norway) and Abdelillah Hamdouch (University of Tours, France).

(C) 2019 by the authors; licensee Cogitatio (Lisbon, Portugal). This article is licensed under a Creative Commons Attribution 4.0 International License (CC BY).

\section{Introduction}

A dominant trend in contemporary planning is the need to open up planning processes to new voices and perspectives (Albrechts, 2002; Campbell \& Marshall, 2010; Fung, 2015; Lundman, 2016; MacCallum, 2010; Monno \& Khakee, 2012). Both in the Nordic countries as well as internationally, we are witnessing a number of new and more participatory forms of interactions between citizens and local authorities (Healey et al., 2008; Sørensen \& Torfing, 2018). Some of these participatory practices are being exercised in the periphery of-or only loosely linked to-the formalities of planning processes and operate under different umbrellas, for instance Do-
It-Yourself urbanism (Talen, 2015), insurgent planning (Miraftab, 2009), everyday urbanism and guerrilla urbanism (Simpson, 2014). These initiatives are often taken by citizens and manifest as protests or opposition towards the authorities (Agger \& Sørensen, 2014; Nyseth \& Ringholm, 2018; Umemoto, 2001). However, local authorities also experiment with new forms of participation. In this article, we will analyse three examples of innovative initiatives aiming to involve citizens in formal planning and urban governance processes initiated and organised by the planning authorities.

In a number of transformative urban programs, citizens' input is valued for different reasons (Sørensen \& Torfing, 2018). Urban planning and development have 
become a testing ground for different forms of experiments (Evans, Karvonen, \& Raven, 2016; Lim, 2016; Marvin \& Silver, 2016). Under the umbrella term of "urban laboratories", a collection of methods has been developed for organising urban experiments. Increasingly, they have moved beyond the merely technical and towards a social profile (Karvonen \& van Heur, 2014), meaning that they emphasise interaction and deliberation among stakeholders in different formats such as, for instance, charrettes, café dialogues, consultations, deliberative panels, workgroup weekends, forecasts, and art interventions. Some of these initiatives may be described as "democratic innovations"; understood as institutions that have been specifically designed to shift the understanding of citizen participation in the political decision-making process (Smith, 2009). Experiments like "The City Development Year in Troms $\varnothing$ " (in 2005-2006) and "Experiment Stockholm" (in 2015) were innovative in their approaches to imagining urban futures for the city through a number of multi-actor workshops, reframing the planning discourse, and staging events that occasionally created moments of magic (Nyseth et al., 2010; Smas, Schmitt, Perjo, \& Tunström, 2016). Advantages accruing to the use of temporary spaces as places for artistic experiments in visualising possible futures (Haydn \& Temel, 2006; Metzger, 2010) or as sites for pop-up events that can serve as arenas for community action (Madanipour, 2017) have progressed. In the field of areabased urban governance, for instance, new forms of citizen participation have been launched in connection with new ideas about how public authorities can work more strategically in order to mobilise civil society actors to coproduce public services, particularly in Denmark (Agger \& Tortzen, 2015). In the majority of these initiatives, citizens are expected to play an important role in coproducing joint solutions for both social and physical improvements with public authorities in their neighbourhood (Agger \& Jensen, 2015; Agger \& Andersen, 2018; Agger \& Tortzen, 2018). Programs with similar aims exist in Norway as well (Ruud \& Vestby, 2011).

A motivation behind the innovative forms of citizen participation is the difficulties that traditional and more formal arenas for participation have in reaching a broad scope of citizens and other stakeholders. Another motivation is the need for cities to signify their openness to diversity in ways of living, interests, and ethnicity. Particularly in larger cities, policies targeting social cohesion and branding the cities as being open and inclusive is a new trend, partly as a critique of the entrepreneurial focus dominating urban strategies of the 1990s (Florida, 2014). "Social innovation", which in urban development focuses on processes aimed at countering social exclusion, has gained importance (Gerometta, Häussermann, \& Longo, 2005, p. 2007) as a result of this trend. What we are witnessing is an increased interest in the transformative power of urban planning through social innovation (Moulaert, 2016). Although there are multiple interpretations of what social innovation implies, there is a general consensus that 'processes' between citizens and public authorities is considered valuable for the legitimacy of the public sector (Bekkers, Tummers, \& Voorberg, 2013).

The interest in social innovation in urban planning has resulted in a number of "democratic innovations" in the sense that citizen participation is being framed differently from the traditional forms; public meetings and hearings with an emphasis on more interactive and participatory elements. These participatory initiatives most commonly start with a "problem" that needs to be solved or a new possibility opened up, and then involve the public/civil society, corporate organisations, and networks, in order to build collaborative institutions that work. Although we find that these new venues for participation have the potential for recruiting a broader scope of actors, we also find that there are some important aspects that haven't been discussed in the scholarly debate.

First, some of these new forms of participation are not necessarily designed according to democratic principles such as inclusion, transparency, and accountability. These venues might still strengthen democracy by including new actors. However, they may lead to the participation of resourceful citizens claiming to talk on behalf of their locality. Second, they are aiming at outcomes other than those of mandatory planning, including features such as creating greater public value, contributing to social innovation, and putting new ideas on the agenda (Demazière et al., 2017). Third, they are often motivated in a context of uncertainty and the need to mobilise new resources into transformative actions (Healey, 2007). For these reasons, the innovative forms of citizen participation also represent a risk to democracy, and we have both sides of risk in mind; the possibility of strengthening as well as weakening democratic standards.

In this article, we will explore certain aspects of these forms of participation and their potential contribution to social innovation. We will base the analysis on three case studies of innovative citizen participation framed as forms of experiments aiming at creating a greater public good. The article is structured as follows: we start by reviewing concepts of social and democratic innovation, creative experimentation, and co-creation as approaches to analyse new modes of citizen participation. Next, we present three examples of innovative forms of citizen participation in invited spaces from Norway and Denmark. In the discussion, we consider the democratic implications of the extended repertoire of techniques used to include citizens, which is otherwise difficult to reach, and create new arenas for interaction and collaboration. Finally, we have investigated how the results of these forms of participation are incorporated into formal processes of planning and decision making.

\section{Social Innovation, Planning and Empowerment}

The field of social innovation has literally boomed in the last couple of decades, driven by such trends as the engagement of citizens and organisations in inno- 
vation, criticism of dominant business models, and narrow economy outlooks on development (van der Have \& Rubalcaba, 2016). Social innovation is understood as new ways of creating and implementing social change (Hochgerner, 2011). The focus is on practices and on the way they are combined. Innovation has become more about solving social problems than about new technology as, for instance, stated in the European Commission $(2013$, p. 6) guide to social innovation: "social innovation can be defined as the development and implementation of new ideas to meet social needs and create new social relationships or collaborations". Starting out largely as a political agenda, more analytical approaches have recently been developed. Across the diverse and fragmented literature, two core components appear to be shared. Social innovation encompasses: 1) a change in social relationships, systems, or structures, and 2) such changes serve a shared human need/goal or solve a socially relevant problem (van der Have \& Rubalcaba, 2016). Following Moulaert, MacCallum, Mehmood and Hamdouch (2014), we would add empowerment as a third dimension, as the engagement of citizens is essential to promote social innovation, in particular by giving voice and power to marginalised groups. In accordance to Voorberg, Bekkers and Tummers (2015, p. 1347), we understand social innovation as:

The creation of long-lasting outcomes that aim to address societal needs by fundamentally changing the relationships, positions, and rules between the involved stakeholders through an open process of participation, exchange, and collaboration with relevant stakeholders, including end-users, thereby crossing organisational boundaries and jurisdictions.

This is a perspective that emphasises the improvement of the quality of life of people where development has a more active meaning aimed to transform relationships and shift trajectories (Gonzales \& Healey, 2005). Therefore, successful social innovation that leads to social value creation understood as empowerment, reciprocity, and improved relations among the participants is often constructed in a multi-stakeholder setting where competing values have to be dealt with. Social innovations are often co-produced with participating actors from both civil and government sectors of society.

\section{Planning as Creative Experimentation and Co-Creation}

The interest in finding new ways to interact with public and private actors has, within the field of planning, given rise to an interest in new approaches and practices. For Jean Hillier, experiments are speculative methods of knowing, working with doubts and uncertainty, without knowledge of where one ends (Hillier, 2008). New energies might be mobilised in such transformations, in which there are losers as well as winners, and there may be hegemonic forms of representation (for instance, interest groups of NIMBYs). It is, in Hillier's view, important for planners to organise "good encounters", in which powers of acting and the active effects that follow them are increased; a more inclusive, open, creative, and democratic planning, where possible future scenarios and collaborative, critical discussion about their potential consequences for different actors are called for. The experimental planning approach challenges the framing of participation both with regard to form (performance) and inclusiveness. This approach to participation also finds resonance in the growing literature on the concepts of "co-creation" and "co-production" that are prominent in the discussion on public innovation (Sørensen \& Torfing, 2018; Torfing, 2016). These are essential elements in the line of thought that is described as network governance, co-management, and co-production (Hartley, Sørensen, \& Torfing, 2013), and summed up as being part of a new perspective on steering under the label 'New Public Governance' (Osborne, 2006). This development is characterised by increased involvement of actors from the business sector, third sector actors, and users in different phases of policy-making, emphasising the collaborative aspects of the innovation process. The participation aspect comes from the literature on collaborative innovation, user-driven innovation (Bason, 2007), employee-driven innovation (Karlsson, Skålèn, \& Sundström, 2014), and public value co-creation (Moore \& Benington, 2011). The aim of this can be summed up as twofold: to involve citizens/users in policy-making and to produce good policies that lead to different aspects of public value (Alford, 2010; Bovaird \& Loeffler, 2012; Bryson, Sancino, Benington, \& Sørensen, 2016).

In other words, our approach to the innovative forms of participation are inspired by different, but related, strands of theory. What is striking in the different contributions is that the democratic aspect has not been the most central issue in these studies, even if there are exceptions (Agger \& Löfgren, 2008; Shakeri, 2011).

The core question in this article is thus: how does the innovative participation that is carried out in experimental forms hold the democratic potential that the idea of social innovation rests on? As mentioned, innovation contains risk (Osborne \& Brown, 2013). One democratic aspect may be countered by another. Hence, social innovation could have both winners and losers (Nicholls, Simon, \& Gabriel, 2015). In this analysis, we are guided by the concept of inclusiveness. This is at the core of social innovation ambitions. It is also an essential "democratic good" (Smith, 2009) and an evaluation criterion of innovative participatory democracy (Geißel, 2013). Inclusiveness can, however, manifest itself in different ways, for instance, by how open the invitation to participate is, when and how the participation will take place, and what activity it is organised around. We will emphasise that inclusiveness is also about the degree to which the views and impulses from the participation are being channelled into the decision process. If participation is 
not being channelled into the decision making process, then participation aligns with what Arnstein (1969) labels "therapy". We have, therefore, calibrated inclusiveness into a set of three research questions that will guide the analysis:

1) Are the planning authorities able to mobilise new groups that otherwise are difficult to reach?

2) Do they create new arenas for communication and collaboration?

3) How are the experiences from the participation fed into the formal and decision-making part of the planning process?

\section{Methods and Data}

The three examples, selected to illustrate new forms of citizen participation, have been chosen on the basis that they all display innovative forms of participation with the purpose of enhancing the inclusiveness of citizens in urban planning. They are, however, not intended to be representative. With regard to innovativeness, we refer to the Schumpeterian, contextualised definition of innovation (Schumpeter, 1934/1975). This means that what we define as innovative forms of participation are not entirely novel forms, but forms that are new in the particular context. In this case, the context is the cities where the form is applied. The first example discussed is from Troms $\varnothing$, a medium-sized city located in the northern part of Norway. The example comprises a participatory experiment on visioning the future. The data came from a number of sources because author Nyseth followed the project over a period of one year (in 2015-2016), through on-site participatory observation, by taking part in the events as a citizen in the city, and, on one occasion, as a speaker at one of the meetings. This enabled direct access to the empirical field. In addition, a diverse collection of documents relating to the project has been analysed. The project was well-documented in plans, papers, websites, evaluations, and summaries of events. The second case is from a small city called Kongsvinger, in southern Norway. Based on public documents and qualitative interviews with three of the organisers, Ringholm investigated the participatory processes of the Kongsvinger Urban Lab. This was part of a master planning process which took place in 2015-2017. The third example draws on a study of urban regeneration in the form of areabased initiatives (ABIs) in Copenhagen, Denmark. Empirical data was collected by Agger between September 2015 and May 2017 and consist of qualitative interviews with planners, as well as documental analysis of formal and informal plans regarding the tasks and activities in the $A B I$.

\section{Tracing Novel Patterns of Participation}

The three examples presented below are analysed through the lenses of social innovation, creative experimentation, and co-creation. In terms of social innovation, we question whether the planning authorities are able to reach and mobilise new groups that otherwise are difficult to reach. In terms of creative experimentation, the level of initiating and implementing a testing ground for inviting in new perspectives on urban development is a criteria. In terms of co-creation, forms of collaboration between a broad set of actors are addressed, as well as the potential impact these activities have in the more formal phases of the planning and decision-making process.

\subsection{Case 1. Multiplicity: "Where Is Tromsø Going?"}

As one of the fastest growing cities in the country for more than 30 years, Troms $\varnothing$ has experienced an intense transformation of the urban landscape that affects citizens' everyday lives and their identification with the place. To involve the citizens in future plans for development has therefore been an issue. The case discussed here, entitled "Where is Troms $\varnothing$ going?" was a project intended to reflect the future of the city, and took place in 2015-2016. A range of different participation methods was used-hence the label "multiplicity". The City has a long history of thinking about and carrying out experimental methods in urban planning. From the 1990s and onwards, a number of new collaborative planning projects were introduced in order to involve and commit stakeholders and involve citizens in urban transformation projects (Nyseth, 2011; Nyseth et al., 2010).

This project took place as part of a formal planning process related to a municipal master plan. The project invited citizens to think about and plan the future of the city. One of the arguments for the project was that "citizen participation, as it is practiced today by the Troms $\varnothing$ municipality, is hardly according to the minimum requirements in the Planning and Building Act". One of the aims of the project was therefore to explore new methods of participation. The initiative was organised as a project and, in that sense, given more autonomy to go beyond authoritative planning procedures and still be a part of the "system" because it was linked to a formal planning process.

The methods used to involve citizens in the project were multiple. Citizens were invited to participate in public meetings, philosophical conversations, city walks highlighting local heritage, cultural events, workshops, democratic cafés, seminars, and exhibitions. In addition, films with topics related to urban planning were shown at a cinema followed by discussions and lectures were given, blogs produced, and chronicles written and published both in the local newspapers and in special publications of "small papers".

Among the most creative and innovative forms of participation was the interactive website based on the MyCity concept. This was a digital platform of communication that used interactive mapping technology which allowed citizens to post their views and suggestions to improve their city online on a virtual map. A summary of the ideas was published in an exhibition. All citizens 
were invited and the invitation to participate was worded as follows: "Do you have an idea, dream, or opinion about the future of Troms $\varnothing$ ? Share your views here: tromso.mycity.io!" By clicking on the map, citizens could publish comments for others to read, vote for, or peruse. Citizens were invited to suggest the unused potential in the city and suggest solutions that could improve the quality of the community. Relevant suggestions were to be absorbed into the municipal master plan. Altogether, 173 suggestions were posted on the website. The aim was both a democratic experiment generating commitment and engagement of citizens as well as collecting as many practically implementable ideas as possible for the pending area-planning phase.

Another method was organising workshops with young people. Two workshops about future visions were organised. One focussed on architecture in which school children were introduced to thinking about the future through architecture. The other workshop was a documentary film project. Another example of innovative methods was the use of pop-up art and cultural events. The idea was to visualise potentialities.

Among the more obvious outcomes of the project were all the suggestions that were posted on the website; some of these ideas were absorbed into the formal planning process for further consideration. It is, however, very difficult to find any concrete references to these suggestions in the actual plan. More material outcomes were a number of published "small papers" which documented all the ongoing sub-projects. These papers were not academic papers, but had a format that was very accessible, with many visualisations, and easy to read. The project became a testing ground for new ways of reaching out to new citizens using other forms of communication. All the lectures, seminars, and events had quite a number of participants and, although the audience in most of the seminars was more or less composed of the same people, the cultural walks and the workshops with schoolchildren did invite and recruit other audiences. The project mobilised new actors in citizen participation-people who probably would not have participated in public meetings; for instance, schoolchildren. The performance aspect was also important. Young people "doing" planning through city walks, drawings, filmmaking, and other forms of visualisations engaged with and built knowledge about planning in a much more solid way than could be inspired by hearings or meetings. On a more general level, some of these methods have become a part of the standard procedure in the city planning office toolkit, also involving the department of culture in order to use art and cultural expressions as a means of making citizen participation more interesting.

\subsection{Case 2. Mobilising the Commons: Stories from the AlBs in Copenhagen}

Just as in other metropolitan cities, Copenhagen is challenged by some neighbourhoods that fall behind the rest of the city with regard to the high level of ethnic minorities, people not engaging in the workforce, and young people dropping out of education (Municipality of Copenhagen, 2012). This has resulted in a number of initiatives- among which urban renewal initiatives are integrated (Municipality of Copenhagen, 2012) that address physical improvements and social activities. In Danish, these initiatives are called Områdefornyelser which translates as ABIs.

$A B l s$ are partly funded by the state and partly by municipalities and runs for a period of five years. Each site has a local secretariat, staffed with four to eight people who are typically architects, public administrators, geographers, and social scientists. Part of their way of operating is that it is essential to mobilise local actors to enact citizenship and to care about their neighbours and neighbourhoods. They do so by trying to constitute the deprived neighbourhood as a common place, i.e., an entity for local action and for living a quality life with your neighbours, thus the title; mobilising the commons.

The ABIs methods of involving citizens included a range of different and innovative participatory approaches in order to reach out. Of particular importance are the methods used to connect with certain groups that are often difficult to reach, e.g., ethnic minorities, youth, busy families, or homeless groups. One type of approach they frequently apply is inspired by field approaches used in anthropology, organised by planners as "study trips" in order to feel the environment and to talk to people in the locality. An example of this took place in Nørrebro, where a local plan for traffic solutions was to be debated. Prior to the meeting, the planners went out in the neighbourhood and carried out a number of qualitative interviews with young immigrants who would not attend public meetings. At the coffee table in the meeting room, the perspectives of some of the young people were represented on posters in the form of quotes in speech bubbles. During the debate, the facilitator requested the audience to take these perspectives into consideration.

Another approach is design-thinking; for instance, experimenting with prototyping urban installations in the form of temporary projects which could take the form of converting parking lots to green spaces by installing artificial grass and benches. The idea is to test different uses of public spaces and to catch the attention of passers-by who normally would not participate in a meeting about the development of their neighbourhood. Other examples are projects that aim to show 1:1 scale installations using temporary materials to give an idea about the size and function of the planned installation. One example of this occurred in the $A B I$ in Valby, where a local square was transformed into a temporary garbage collection station. The whole idea of placing a garbage station in a rather dense urban neighbourhood would normally lead to much protest and conflict. However, by using temporary testing it was demonstrated that the garbage station could also carry out other functions and serve as a 
local meeting place. The temporary installation helped to not only capture a broad group of local residents that passed by, but it also managed to qualify local deliberations about where to locate the garbage station.

The example of the Danish ABls shows that they are able to mobilise groups that are otherwise difficult to reach. They do so by applying anthropological methods, that 'go to the field' where these groups are present, and by creating an arena where local actors and networks can meet and deliberate. Many of these networks work sideby-side in the neighbourhoods, but often they have no knowledge of the existence of the other actors or are too occupied with their own agenda to see the value of collaboration. Thus, in a sense, the participation is organised top-down, but with the intention of kick-starting bottomup processes of empowerment. The potential impact of these approaches is twofold. First, the $A B I$ approaches mobilise local actors and contribute to creating local action capabilities among different local actors. However, it is usually the most resourceful actors who participate in these arenas. Second, when these approaches are coupled with design-thinking and anthropology tools, then the potential impact of reaching a broader group of actors is high. The potential impact of these modes of participation is difficult to assess in a general manner. However, we noted that when local actors managed to agree on a particular matter, the city council would often approve the projects. Nevertheless, there were also incidents where local actors agreed on a topic that was against the majority of the city council and, therefore, impossible to implement, to the frustration of the local actors.

\subsection{Case 3. Regeneration Strategy through} Participation: CityLab (ByLab) In Kongsvinger (Norway)

The CityLab in Kongsvinger was connected to a city development process, which was also connected to transport planning in the area of the city and its surroundings. The aim was to chisel out a development strategy for the city area-Kongsvinger 2050. The general political backdrop for initiating the city development strategy consisted of three main factors. Firstly, an ageing population prompted a general agreement that the municipality should take measures to inspire young people to come forward with their wishes and expectations about the future of the municipality. Secondly, a plan for necessary changes in the road system was coming up. Thirdly, the municipality had urban regeneration aspirations intended to bring new life into the city centre, particularly to attract young people. The process should, therefore, include a broad set of participatory efforts.

The entire planning process was carried out in the period from autumn 2015 to winter 2017 and several participatory measures were taken. The activities and meetings during the process were initiated in collaboration between Kongsvinger Municipality, Hedmark County Authority, the national road authorities, and Our City Kongsvinger (Byen vår Kongsvinger), a network or- ganisation open to business actors, organisations, and individuals which advocates for activity in the city.

The planners argued for new and untraditional ways of participation, in particular those which would engage young people. Insights from citizens, in general, were also welcomed and a set of events with a broad scope with regard to the age and institutional affinity of the participants was designed.

The methods of involving citizens included a range of different activities, starting with in-house preparatory work and a start-up conference focusing on everyday experiences from different parts of the city. In the first phase (2015-2016), three workshops were carried out: 1) the "Youth Workshop" with the youth council in October 2015, 2) the "Business Workshop" with business actors in November 2015, and 3) the "City Seminar" which included a broader spectrum of citizens, in January 2016. These were carried out in the form of group discussions where each group summed up their inputs regarding the process in a document that was handed in to the planning committee. In the second phase, a "Future Workshop" and a public meeting took place, both of which included a diverse set of citizens. Two categories of groups were in action: 1) invited participants from different societal sectors, such as the business sector and the voluntary sector, and 2) an open group where anyone could attend. The third phase, which was the innovative form in this context, was organised as a CityLab over one week and marked the final part of the participatory efforts.

The purpose was to gather insight for developing future images and concept development. A CityLab had not been carried out in this municipality before. The whole process itself was also innovative in the way that the collaborating partners (Kongsvinger Municipality, Hedmark County Authority, the national road authorities, or Statens vegvesen, and Our City Kongsvinger, or Byen vår Kongsvinger) had not carried out a participationbased planning process of this kind and volume before. The CityLab was organised as a combination of meetings in new arenas, visits to different workplaces, politicians' lunch in the pedestrian street, politicians' sofa, collections of written suggestions, taking photos of important places, and it involved children and young people. The CityLab certainly managed to create new arenas and engage people who are, in general, difficult to engage in municipal planning; particularly children, youth, and people who are not engaged in organisations that are normally included in participative planning. However, while it is fairly easy to map the arenas, it is far more difficult to get the full picture of who the participants in the arenas were. Some are straightforward, like school classes and workplaces. Others are impossible to map, like the city walks, the politicians' sofa, and collections of suggestions and photos. The participants in those arenas were not filed and mapped.

The inputs from workshops and other events were summed up and reported on. The project's homepage 
made all these documents accessible and enabled responses. The policy documents that presented the "future pictures" to the business and city development committees, to a certain degree, summed up experiences and views from the different components of the whole process. It is, however, difficult to trace which event and what stage of the process the knowledge and viewpoints came from by simply reading the policy document, as this document is short and refers to the process in general terms. In other words, the "tidier" forms of participation, workshops, and formal meetings are possible to identify in the documents, while the "untidy" forms tend to become invisible. When considering how traceable the inputs from the process are in the policy document, however, we must take into consideration that this is a strategy document and that there is a possibility that the inputs will be more concretely traceable in later phases, when the strategy is translated into zoning plans and area zoning plans. The findings from the three examples are summarised in Table 1.

\section{Discussion}

In this article, our intention was to explore the democratic potential of new forms of citizen participation in the field of urban planning and governance. Social/democratic potential was particularly addressed through inclusion and operationalised into two questions: 1) To what degree are these forms of participation able to include new groups of citizens? 2) Did they manage to create new arenas for interaction and collaboration? What the three examples have in common is that they experimented with-for the planners involvednew modes of interacting and reaching out to affected citizens. The most inclusive methods used to reach out to citizens that are otherwise difficult to reach are the

Table 1. Summary of the three examples.

\begin{tabular}{llll}
\hline & $\begin{array}{l}\text { Multiplicity: Where is } \\
\text { Troms } \varnothing \text { going? }\end{array}$ & $\begin{array}{l}\text { Mobilising the commons: } \\
\text { ABI in Copenhagen }\end{array}$ & $\begin{array}{l}\text { Regeneration strategy } \\
\text { through participation: } \\
\text { CityLab in Kongsvinger }\end{array}$ \\
\hline $\begin{array}{l}\text { Forms of social innovation } \\
\text { (inclusion) }\end{array}$ & $\begin{array}{l}\text { Invited people with different } \\
\text { backgrounds, interests, and }\end{array}$ & $\begin{array}{l}\text { Mobilise local actors by } \\
\text { creating new arenas for }\end{array}$ & $\begin{array}{l}\text { Inspired young people, in } \\
\text { particular, to come } \\
\text { - New arenas }\end{array}$ \\
ages to form views about & participation; Open, hang out forward \\
the future of Troms $\varnothing$. & spaces in the neighbourhood; New arenas: shopping \\
New arenas; cafes, & Reach out to hard to reach & School visits \\
the street, the web & groups, e.g., busy citizens, mall, pedestrian street, \\
& families, ethnic minorities; & work-places
\end{tabular}

Forms of experimentation

- Methods of involvement

- Level of "testing"

\author{
Public meetings; \\ City walks; \\ Philosophical conversations; \\ Cultural events; \\ Democracy cafés; \\ Blogs; \\ Chronicles; \\ Interactive web; \\ Workshops
}

Field approaches to connect with citizens;

Qualitative interviews; Temporary installations as tests and to create attention
Politicians' sofa: sofa manned two hours a day by a politician; CityLab on tour: seven planners and politicians visit workplaces and meeting places City talk in the mall; Politicians' city lunch in the pedestrian street; The thought-catcher: notes that people can post on a map to state a view;

Sketches and 3D glasses to visualise future Kongsvinger.

Multi-level \& cross-sector: Collaboration between the municipality, Hedmark County Authority, the national road authorities, and Our City Kongsvinger. 
examples of Case 2, "Mobilising the Commons". The ABI officers' efforts to reach out to, for instance, migrants through ethnographic methods are unique. By bringing planners and public administrators to the streets and public spaces where citizens socialise, they were able to directly interact with citizens in the neighbourhood. It was possible to reach those who never attend public meetings, create dialogue on the spot, and consider alternative views and inputs. Also, in the two other examples, new groups of citizens, particularly young people, were included through new approaches and methods, for instance, filmmaking, interactive web, and cultural events. A mall, a street, a café, or a workplace can become arenas for citizen participation and interaction.

By using new methods for expressing views about qualities of place, all three examples also created new arenas for dialogue among citizens and experts. Such arenas can function as a form of intermediary institutions between actors in the neighbourhood, as well as between the neighbourhood and local government (Agger \& Jensen, 2015, p. 2059). At their best, these innovative forms of participation might contribute to a "third space" (Firth, Maye, \& Pearson, 2011) or what Fung calls "cold deliberative settings" (Fung, 2003). In "hot" settings, the stakes are set and views are strongly formed; stakeholders are therefore hardly persuaded by others arguments. "Cooler" settings are often more informal and unofficial, and have a more advisory function; less is directly at stake, which also opens up the possibility of minds being changed without any risk for the stakeholder. Such spaces can sometimes open up quite unexpectedly (Metzger, 2010, p. 218) or, as in these examples, be deliberately designed and facilitated.

The examples presented in this article do not represent methods and techniques which aim at increasing citizen participation that are completely unknown. What makes them interesting, however, is the compilation of a broad variety of methods which involve citizens and create an assortment of participation in one and the same process; as such, this illustrates the diversity of participatory development. The examples display a mix of participatory forms, with different degrees of staging. Some parts of the initiatives and processes were more orchestrated by the planners than others. Such processes can be achieved through the arrangement or creation of a new physical environment to meet in, or through changing the technologies, for example through the use of social media and web-based forms of interaction.

As for the third question about how the experiences from the participation are fed into the formal and decision making aspect of the planning process, the answer is more ambivalent. Some of these forms of participation seem to provide new forms of openings towards new ideas, opinions, and imageries that could increase the quality of a plan. On the other hand, there are also shortcomings when it comes to concrete and tangible results in the form of direct inputs to a plan. In the Multiplicity case, a decision vacuum occurred in the phase when the project was finished, and the experiences were supposed to be transferred and linked to the standard operating procedures and routines of the municipal planning office. Experiments such as these often lead to conflicts with city governments on how to use places in a somewhat orderly fashion (Groth \& Corijn, 2005). The middle ground, which is an advantage in the creative phases of the process, becomes a disadvantage when results are due to be translated into the formal planning process. The question of how a participatory process might inform a final plan is often not articulated. The conservativeness of the plan as a genre might be an explanation as to why this seems to be so difficult to change (MacCallum, 2008). Another problem related to these forms of settings, from a democratic point of view, is that they do not provide a high degree of transparency or accountability. In addition, there is probably a need to dig deeper into the possible outputs of participation, other than simply looking for them in the corresponding policy documents. These processes are just as much aimed at having an impact on the mindset of citizens, planners, and politicians, both with regard to quality of place and with regard to an understanding of how participation should take place. As such, it is possible that they better correspond with the expressive side of participation than with the instrumental side (Pateman, 1979). Such aspects are in line with a great part of the social innovation literature that underlines the transformative power in contributing to the development of new roles, mindsets, and discourses.

\section{Conclusion}

Citizen participation has to be reconsidered in a form that is relevant to the particular context, to the particular policy problem, and to the interests that are affected. In this sense, experiments may function as a frame for testing out new forms of participation adapted to the particular context, its challenges, and the citizens being addressed. Efficient participatory methods require design; they do not simply happen through, for instance, open invitations to public meetings. These methods need to be tailored to fit the context and its challenges (Agger, 2012). Offering a new forum for interaction with a diversity of actors, methods such as urban living labs, and other forms of experiments can be used to establish a defined space for experimentation where users become co-creators of values, ideas, and innovative concepts (Hakkarainen \& Hyysalo, 2013, p. 21). Perhaps this search for novel ways of addressing participation is an expression of public planners' and politicians' recognition of the New Political Culture (Clark, 2014)-that citizens communicate through different channels than before and, in order to involve them, planners and politicians need to meet them where they are: in the streets, in the shopping malls, in the cafés. These are the scenes where the buzz is happening, and planners need to keep their fingers on the pulse (Clark, 2014). Experiments are understood to be contingent and open-ended, carrying 
a risk for losses as well as rewards (Karvonen \& van Heur, 2014 , p. 386). Co-creation, urban lab experimentation, and other forms of experiments such as cultural events illustrated by the terms buzz and scene do, however, have shortcomings in terms of democratic legitimacy, tendencies towards either unlimited inclusiveness or, on the other side, exclusiveness, and extreme temporality. In that respect, they contrast with the "tidiness" of more traditional forms of participation. That said, we do not argue that one should dismiss the "untidy", innovative, and experimental forms because of the risk of losing in some aspects of democracy. Rather, we believe that the research should delve into the questions that arise in the wake of this development, in order to detect new connections. There is a need for the right set of tools to process the inputs from the experiments into the plan documents and the decision process. Herein is also a need for tools for assessing the democratic values that are honoured in the experiments and those that are not.

\section{Acknowledgments}

The research on the two Norwegian cases was carried out as a part of EVAPLAN, an evaluation of the Norwegian planning and Building Act, funded by the Norwegian Research Council (2014-2018). The Danish case is part of the project "Communities in transition: New methods and approaches in mobilizing local stakeholders" and was financed by the Ministry of Housing, Urban, and Rural Affairs in Denmark. We would like to thank the editors and the two anonymous reviewers for constructive feedback on the article throughout the process, and for comments by Hege Hofstad at ECPR 2018, where the paper was presented. The publication charges for this article have been funded by a grant from the publication fund of UiT, The Arctic University of Norway.

\section{Conflict of Interests}

The authors declare no conflict of interests.

\section{References}

Agger, A. (2012). Towards tailor-made participation: How to involve different types of citizens in participatory governance. Town Planning Review, 83(1), 29-45.

Agger, A., \& Andersen, C. K. (2018). Stedsans: Samskabelse gennem omverdensinddragelse [Sense of place: Co-creation through stakeholder involvement]. Trafik og byggestyrelsen. Retrieved from www. trafikstyrelsen.dk/ /media/Dokumenter/10\%20Bolig /Publikationer/Stedsans\%20-\%20samskabelse\%20 gennem\%20omverdensinddragelse.pdf

Agger, A., \& Jensen, J. O. (2015). Area-based initiatives and their work in bonding, bridging and linking social capital. European Planning Studies, 23(10), 2045-2061.

Agger, A., \& Löfgren, K. (2008). Democratic assessment of collaborative planning processes. Theory, $7(2)$, 145-164.

Agger, A., \& Sørensen, E. (2014). Designing collaborative policy innovation: Lessons from a Danish municipality. In C. Ansell \& J. Torfing (Eds.), Public innovation through collaboration and design (pp. 188-208). New York, NY: Routledge.

Agger, A., \& Tortzen, A. (2015). Forskningsreview om samskabelse. Vejle: University College Lillebaelt. Retrieved from samskabelse.ucl.dk/files/2015/02/ forskningsreview-om-co-production_samlet-udgaveat-aa-at07115-2.pdf

Agger, A., \& Tortzen, A. (2018). Hvilken værdi skaber vi med samsabelse-og hvordan kan den måles og dokumenteres? [What value is created through co-production; and how can it be evaluated and assessed]. Professionshøjskolen Absalon. Retrieved from phabsalon.dk/fileadmin/user_upload/ CV/Hvilken_vaerdi_skaber_vi_med_samskabelse.pdf

Albrechts, L. (2002). The planning community reflects on enhancing public involvement. Views from academics and reflective practitioners. Planning Theory \& Practice, 3(3), 331-347.

Alford, J. (2010). Public value from co-production with clients. In M. H. Moore \& J. Benington (Eds.), Public value: Theory and practice (pp. 144-157). Basingstoke: Palgrave Macmillian.

Arnstein, S. (1969). A ladder of citizen participation. Journal of American Planning Association, 35(4), 216-224.

Bason, C. (2007). Velfærdsinnovaion. Ledelse av nytenkning $i$ den offentige sektor. København: Børsen Offentlig.

Bekkers, V., Tummers, L., \& Voorberg, W. (2013). From public innovation to social innovation in the public sector: A literature review of relevant drivers and barriers. Rotterdam: Erasmus University. Retrieved from www.lipse.org/userfiles/uploads/From public innovation to social innovation in the public sector.pdf

Bovaird, T., \& Loeffler, E. (2012). From engagement to coproduction: The contribution of users and communities to outcomes and public value. VOLUNTAS: International Journal of Voluntary and Nonprofit Organizations, 23(4), 1119-1138.

Bryson, J., Sancino, A., Benington, J., \& Sørensen, E. (2016). Towards a multi-actor theory of public value co-creation. Public Management Review, 19(5), 1-15. https://doi.org/10.1080/14719037.2016.1192164

Campbell, H., \& Marshall, R. (2010). Public involvement and planning: Looking beyond the one to the many. International Planning Studies, 5(3), 321-344.

Clark, T. (Ed). (2014). Can Toqueville Karaoke? Global contrasts of citizen participation, the arts and development Research. Bingley: Emerald Group Publishing.

Demazière, C., Hamdouch, A., Nyseth, T., Førde, A., Serrano, J., \& Aarsæther, N. (Eds.). (2017). Creative approaches to planning and development in small \& medium sized towns. London: Routledge. 
European Commission. (2013). Social innovation research in Europe: Approaches, trends and future directions. Brussels: Directorate-General for Research.

Evans, J., Karvonen, A., \& Raven, R. (Eds.). (2016). The experimental city. London: Routledge.

Firth, C., Maye, D., \& Pearson, D. (2011). Developing "community" in community gardens. Local Environment, 16, 555-568.

Florida, R. (2014). The creative class and economic development. Economic Development Quarterly, 28(3), 196-205. https://doi.org/10.1177/ 0891242414541693

Fung, A. (2003). Recipes for public spheres. Eight institutional design choices and their consequences. The Journal of political Philosophy, 11(3), 338-367.

Fung, A. (2015). Putting the public back into governance: The challenges of citizen participation and its future. Public Administration Review, 75(4), 513-522.

Geißel, B. (2013). Introduction: On the evaluation of participatory innovations. A preliminary framework. I. B. Geißel \& M. Joas (Ed.), Participatory democratic innovations in Europe: Improving the quality of democracy? (pp. 9-32). Opladen: Barbara Budrich.

Gerometta, J., Häussermann, H., \& Longo, G. (2005). Social Innovation and civil society in urban governance: Strategies for an inclusive city. Urban Studies, 42(11), 2007-2021.

Gonzales, S., \& Healey, P. (2005). A sociological institutionalist approach to the study of innovation in governance capacity. Urban Studies, 42(11), 2055-2069.

Groth, J., \& Corijn, E. (2005). Reclaiming urbanity: Indeterminate spaces, informal actors and urban agenda setting. Urban Studies, 42(3), 503-526.

Hakkarainen, L., \& Hyysalo, S. (2013). How do we keep the living laboratory alive? Learning and conflicts in living lab collaboration. Technology Innovation Management Review, 2013(December), 16-22. Retrieved from timreview.ca/article/749

Hartley, J., Sørensen, E., \& Torfing, J. (2013).Collaborative innovation: A viable alternative to market competition and organizational entrepreneurship. Public Administration Review, 73(6), 821-883.

Healey, P. (2007). Urban complexity and spatial strategies. Towards a relational planning for our times. London: Routledge.

Healey, P., Booher, D. E., Torfing, J., Sørensen, E., Ng, M. K., Peterson, P., \& Albrechts, L. (2008). Civic engagement, spatial planning and democracy as a way of life civic engagement and the quality of urban places enhancing effective and democratic governance through empowered participation: Some critical reflections one humble journey towards planning. Planning Theory \& Practice, 9(3), 379-414.

Haydn, F., \& Temel, R. (2006). Temporary urban spaces. Basel: Birkhäuser, Publishers for Architects.

Hillier, J. (2007). Stretching beyond the horizon. A multiplanar theory of spatial planning and governance. London: Ashgate.
Hillier, J. (2008). Plan(e) speaking: A multiplanar theory of spatial planning. Planning Theory, 7(1), 24-50.

Hochgerner, J. (2011). The analyses of social innovations as social practice. In Pendels zwicschen Wissenschaft und Praxis. Zsi-Beitrage zu sozialen Innovatinen (pp. 173-189). Viena and Berlin: LIT; Zentrum fur Soziale Innovation.

Karlsson, J., Skålèn, P., \& Sundström, E. (2014). How frontline employees nurture service innovation through co-creating with their customers: A case study of public health care. In L. Fuglesang \& R. Rønning (Eds.), Framing innovation in public service sectors. New York, NY: Routledge.

Karvonen, A., \& van Heur, B. (2014). Urban laboratories, experiments in reworking cities. International Journal of Urban and Regional Research, 38, 379-392.

Lim, D. (2016). Designing with people and not just for people. ParicipateinDesign. Retrieved from participateindesign.org/shop/designing-with-peopleand-not-for-people-a-publication-by-pd

Lundman, R. (2016). Bringing planning to the streets; using site-specific video as a method for participatory planning. Planning Theory \& Practice, 17(4), 601-617.

MacCallum, D. (2008). Participatory planning and meansends rationality: A translation problem. Planning Theory \& Practice, 9(3), 325-342.

MacCallum, D. (2010). Discourse dynamics in participatory planning. New York, NY: Routledge.

Madanipour, A. (2017). Temporary use of space: Urban processes between flexibility, opportunity and precarity. Urban Studies. Advanced online publication. https://doi.org/10.1177/0042098017705546

Marvin, S., \& Silver, J. (2016). The urban laboratory and emerging sites of urban experimentation. In J. Evans, A. Karvonen, \& R. Raven (Eds.), The experimental city (pp. 1-20). Retrieved from www.routledge.com/The -Experimental-City/Evans-Karvonen-Raven/p/book/ 9781138856202

Metzger, J. (2010). Strange spaces: A ratonale for bringing art and artists into the planning process. Planning Theory, 10(3), 213-218.

Miraftab, F. (2009). Insurgent planning: Situationg radical planning in the global south. Planning Theory, 8(1), 32-50.

Monno, V., \& Khakee, A. (2012). Tokenism or political activism? Some reflections on participatory planning. International Planning Studies, 17(1), 85-101.

Moore, H., \& Benington, J. (Eds.). (2011). Public value: Theory and practice. London: Palgrave Macmillian.

Moulaert, F., MacCallum, D., Mehmood, A., \& Hamdouch, A. (Eds.). (2014). The international handbook on social innovation: Collective action, social learning and transdisciplinary research. Cheltenham: Edward Elgar.

Moulaert, F. (2016). Social innovation, institutionally embedded, territorially (re)produced. In D. MacCallum, F. Moulaert, J. Hillier, \& S. Vicari Haddick (Eds.), Social 
innovation and territorial development (pp. 27-40). London: Routledge.

Municipality of Copenhagen. (2012). Integrated urban renewal in Copenhagen. Municipality of Copenhagen. Retrieved from http://kk.sites.itera.dk/apps/ kk_pub2/pdf/870_hHa1d53AJZ.pdf

Nicholls, A., Simon, J., \& Gabriel, M. (Eds.). (2015). New frontiers in social innovation research. New York, NY: Palgrave Macmillan.

Nyseth, T. (2011). The Troms $\varnothing$ experiment: Opening up for the unknown. Town Planning Review, 82(5), 573-593.

Nyseth, T., Pløger, J., \& Holm, T. (2010). Planning beyond the horizon: The Troms $\varnothing$ experiment. Planning Theory, 9(3), 223-247.

Nyseth, T., \& Ringholm, T. (2018). Medvirkning og (i) demokratiske spennigsfelt. In G. S. Hanssen \& N. Aarsæther (Eds.), Plan og Bygningsloven: En lov for vår tid? Oslo: Universitetsforlaget.

Osborne, S. (2006). The new public governance? Public Management Review, 8(3), 377-387.

Osborne, S., \& Brown, L. (2013). Innovation, public policy and public srvices delivery in the UK. Public Administration, 89(4), 1335-1350.

Pateman, C. (1979). Participation and democratic theory. Cambridge: Cambridge University Press.

Ruud, M. E., \& Vestby, G. M. (2011). Utviklingen av Søndre Nordstrand. Deltakelse og medvirkning fra innbyggerne (NIBR Rapport 2011: 19). Oslo: Norwegian Institute for Regional Research.

Schumpeter, J. A. (1975). The theory of economic development: An inquiry into profits, capital, credit, interest and the business cycle. Cambridge, MA: Harvard University Press. (Original work published 1934)

Shakeri, M. (2011). Democratic assesment of collaborative planning (Unpublished master's thesis). Uni- versity of Twente, the Netherlands. Retrieved from www.itc.nl/library/papers_2012/msc/upm/shakeri.pdf

Smas, L., Schmitt, P., Perjo, L., \& Tunström, M. (2016). Positioning urban labs: A new form of smart governance? In Proceedings from the Real Corp 2016 (pp. 919-923). Hamburg: Real Corp.

Simpson, B. (2014). Insurgent public space: Guerlia urbanism and the remaking of contemporary cities. International Planning Studies, 19(1), 105-108.

Smith, G. (2009). Democratic innovations. Cambridge: Cambridge University Press.

Sørensen, E., \& Torfing, J. (2018). Co-initiation of collaborative innovation in urban spaces. Urban Affairs Review, 54(2), 388-418. https://doi.org/10.1177/ 1078087416651936

Talen, E. (2015). Do-it-yourself urbanism: A history. Journal of Planning History, 14(2), 135-148.

Torfing, J. (2016). Collaborative innovation in the public sector. Washington, DC: Georgetown University Press.

Umemoto, K. (2001). Walking in another's shoes: Epistemological challenges in participatory planning. Journal of Planning Education and Research, 21(1), 17-31.

van der Have, R., \& Rubalcaba, L. (2016). Social innovation research: An emerging area of innovation studies? Research Policy, 45, 1923-1935.

Voorberg, W., Bekkers, V., \& Tummers, L. (2013). Cocreation and co-production in social innovation: $A$ systematic review and future research agenda. Paper presented at the EGPA Conference, Edingburg.

Voorberg, W., Bekkers, V., \& Tummers, L. (2015). A systematic review of co-creation and co-production: Embarking on the social innovation journey. Public Management Review, 17(9), 1333-1357. https:// doi.org/10.1080/14719037.2014.930505

\section{About the Authors}
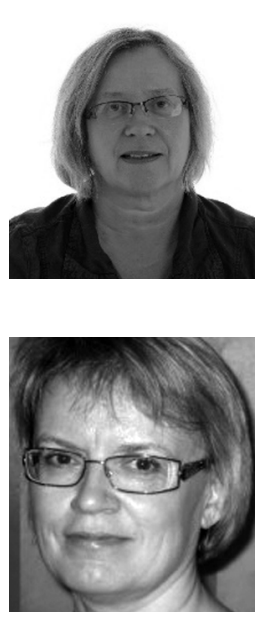

Torill Nyseth is a Professor in Urban Planning at Uit, The Arctic University of Norway. She teaches planning and local development and has published extensively in fields such as urban planning, local development, governance, interactive participation, and place development. Examples of publications are Place Reinvention: Northern Perspectives (2009; with Arvid Viken), Creative Approaches to Planning and Local Development (2017; with C. Demazier, A, Hamdouch, N. Aarsæther, A. Førde and J. Serrano).

Toril Ringholm is an Associate Professor in the Planning Department at UiT, The Arctic University of Norway. Her research interests include participation in public planning, public innovation, and local democracy. These interests come together in the theme of innovative forms of participation in planning processes. She has published several articles, book chapters, and research reports on the themes, and co-edited a book on municipal innovation. 


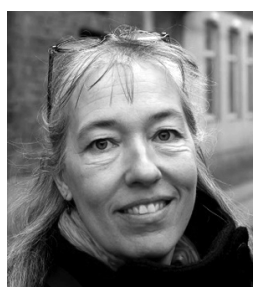

Annika Agger, PhD, is an Associate Professor with a particular focus on citizen participation at the Department of Social Sciences and Business, Roskilde University. Her research field is urban governance and how public authorities can enable inclusive and democratic policies that create public value. 